Volume 19, No 4 International Journal of Radiation Research, October 2021

\title{
Entrance dose determination and effective dose calculation in chest and skull radiographies: an experimental and computational study
}

\section{F. Panahi' ${ }^{1}$ M. Mohammadi², F. Naserpour ${ }^{1}$, N. Hassanpour ${ }^{1}$, M. Gholami ${ }^{*}$}

\author{
${ }^{1}$ Department of Medical Physics, School of Para medicine, Lorestan University of Medical Sciences, Khorramabad, \\ Iran \\ 2Department of Medical Physics and Biomedical Engineering, School of Medicine, Tehran University of Medical \\ Sciences, Tehran, Iran
}

\section{- Original article}

\author{
*Corresponding author: \\ Mehrdad Gholami, Ph.D., \\ E-mail: \\ Gholami.mehrdad@lums.ac.ir
}

Revised: June 2020

Accepted: November 2020

Int. J. Radiat. Res., October 2021; 19(4): 899-906

DOI: $10.29242 /$ ijrr.19.4.899

\begin{abstract}
Background: This study aimed to determine entrance surface dose (ESD), calculate effective dose (ED), organ dose, and local dose levels in three general hospitals of Khorramabad in common diagnostic radiographic examinations, including Chest and Skull. Materials and Methods: Exposure parameters and data of 110 patients were collected during 6 months. In this study, three radiological devices including Shimadzu R-20, Mehran Teb DMT II and Varian Rad-8, were evaluated. Four radiographic views, including Chest posterior-anterior and lateral projections (PA/LAT), and Skull PA/LAT were also assessed. The index used for comparison and measurement of radiation dose was ESD measured using thermo luminescent dosimeter (TLD). In this study, a pc program for Xray Monte Carlo (PCXMC) software was used to calculate the organs' dose and effective dose. Results: The results obtained show that there is a significant relationship between $m A s$ and $k V p$ changes with ED and ESD values. ESD range in Chest PA, Chest LAT, Skull PA, and Skull LAT examinations were $0.1075-0.8844,0.2059-2.2997,0.0729-1.44$, and 0.03478-1.15 mGy, respectively. In this study, the mean ESD estimated was lower than the diagnostic reference levels (DRLS) recommended by the National Radiological Protection Board (NRPB), the Commission of Europian Communities (CEC), and International Atomic Energy Agency (IAEA), but the ED calculated was relatively higher than other studies. Conclusion: A combination of experimental and simulation methods usually makes the accuracy of the dose estimates more reliable. The mean ESD estimated in this study is lower than the DRL published by NRPB, CEC, and IAEA. Also the published ED is almost more than other studies. The results of this study are used to optimize the dose level of patients.
\end{abstract}

Keywords: Patient radiation dose, radiography, effective dose, entrance surface dose.

\section{INTRODUCTION}

The use of ionizing radiation is popular as the most essential human-made source for medical diagnosis in most countries (1). Medical images should provide enough information to make medical decisions with appropriate accuracy. In many cases, higher quality images are obtained using a high rate of radiation, which increases the dose of radiation received by patients (2).The potential risk of losing diagnostic information due to a low radiation dose should be balanced 
against the increased risk of cancer due to ahigher dose (3). Although diagnostic X-ray has many benefits, it is essential for patients and staff to protect against it, as it can be associated with most forms of leukemia and cancers in many organs such as the lung, breast and thyroid gland. Radiation can also cause harmful genetic effects in the children. Most organs and tissues are not affected even by the loss of a large number of cells; however, if the number of cells lost is too high, organ damage can occur and lead them to death. Injuries are usually remedied, but if full remediation does not occur, the changes are transmitted to more cells and eventually lead to cancer (4). To reduce these risks, it is recommended to observe the As Low As Reasonably Achievable (ALARA) principle during radiological examinations ${ }^{(5)}$. Therefore, minimizing the absorbed dose of organs and tissues in radiological examinations as well as using Peak kilovolt age (kVp), Focal-film distance (FFD) and appropriate collimation are essential for optimizing radiological examinations.

To determine the risk in a radiographic examination, it is necessary to know the absorbed dose by each organ and the risk associated. The dose of organs and tissues of patients undergoing $\mathrm{X}$-rays in radiographic examinations is mainly dependent on entrance surface dose (ESD) ${ }^{(6)}$. While assessing ESD is a necessary first step, it is also essential to understand the relationship between ESD and absorbed dose at a depth of tissues. The effective dose is a quantity used to evaluate the probability of cancer and the genetic effects at low levels of ionizing radiation (7). This quantity is not measurable but is computed only by computerized methods, so it is necessary to use models and simulations for estimating effective dose (8). It is essential to compare the dose values measured in different countries with the specific guidelines recommended by relevant organizations such as the National Radiological Protection Board (NRPB), International Atomic Energy Agency (IAEA), and the Commission of Europian Communities (CEC). Diagnostic reference level of quality assurance and quality improvement tools for the control of radiation dose. Diagnostic reference levels (DRLs) acts as a criterion. These organizations introduce the DRL as a standard to optimize radiation protection for patients, and radiation levels should not be higher than acceptable levels according to the International Commission on Radiological Protection (ICRP) statement (9-11). However, in one city, radiology departments may use lower doses than international DRLs. The formulation of DRLs can be effective in reducing the dose received by patients.

In this study, the ESD for Chest and Skull, effective dose (ED), organ dose, and local dose levels are determined for the first time. The presented results are used as preliminary data needed to derive DRLs for X-ray examination in Khorramabad hospitals.

\section{MATERIALS AND METHODS}

\section{Patient study}

In this study, 110 patients who had been referred three public hospitals (hospital A: Shohadaye Ashayer, hospital B: Shahid Rahimi and hospital C: Shahid Madani) in Khorramabad for four radiographic views including Chest Posterior-Anterior and Lateral projections (PA/ LAT) and Skull PA/LAT were evaluated. Data related to the patients were recorded for each radiological examination including age, sex, height, weight, and exposure parameters including $\mathrm{kVp}$, milliampere-seconds (mAs), and FFD. Exposure parameters and patient data were collected over six months. Devices investigated included Shimadzu R-20 (Japan) (Hospital A), MehranTeb DMT II (Iran) (Hospital B), and Varian Rad-8(USA) (Hospital C) in this study. These examinations were selected due to their frequency and collection of significant amounts of data.

Power Analysis and Sample Size (PASS) software with $\alpha=0.05, \beta=0.2$ and $\mathrm{s}=0.81$ to determine sample size, and the least significant difference of the means equal to 9.22, which was obtained from similar studies was used. The sampling method was convenience sampling. The patients' written informed consent was obtained for these tests. Proper shielding was 
performed in these examinations. The Ethics Committee of Lorestan University of Medical Sciences approved thepresent study (IR.LUMS.REC.1396. 272).

It is imperative to use optimal FFD following other exposure parameters, as the direct relationship between low FFD selection and increased patient dose as well as reduced sharpness, is well recognized (12). The radiology technician chooses different $\mathrm{kVp}$, mAs, and FFD range based on various radiographic techniques, patient weight, and thickness. FFD selected in Hospital A was $180 \mathrm{~cm}$ in Chest examination, but it was lower than $\mathrm{kVp}$ in Hospital $\mathrm{C}$, and also the FFD selected was $150 \mathrm{~cm}$.

\section{Radiation dose measurements}

The index used to compare and measure radiation dose was ESD, which was measured using thermo luminescent dosimeter (TLD). For each view, 3 TLD chips packed in plastic nylon were triangularly attached to the radiation center on the patient skin. In this study, TLD (GR200) was used to measure radiation dose (LiF: $\mathrm{Mg}, \mathrm{Cu}, \mathrm{P}$; Radiation Dosimetry TLD, Hangzhou Freq-Electronic Control Technology Ltd, China). Before the test, the TLDs were calibrated to represent the dose in miligray (mGy). A group of TLDs was irradiated with a specific dose in the range of mGy using a diagnostic X-ray $(100 \mathrm{kV}$ and total filtration of 3 $\mathrm{mm} \mathrm{Al}$ ), measured by a $6-\mathrm{cm}$ ionization chamber and a Radical monitor. According to the manufacturer protocol, before and after each use, the TLDs were heated at $245^{\circ} \mathrm{C}$ for 10 minutes and then cooled down to $35^{\circ} \mathrm{C}$. A Calibrated Harshaw 3500 TLD Reader (Thermo Fisher Scientific, USA) was used to heat and read the TLDs. After calibration of the chips, calibration factors were used to read the chips accurately.

For medical exposures, specific conversion coefficients are provided. Effective dose values can be calculated by measurable quantities such as ESD and Dose-Area product (DAP) in radiological examinations $(13,14)$. In this study, a pc program for X-ray Monte Carlo (PCXMC) software based on the Monte Carlo method was used to calculate the organs' dose and effective dose (15). PCXMC 2.0 (STUK, Finland) uses a computational phantom with analytical data based on the Christy and Eckerman mathematical hermaphrodite phantom as recommended by ICRP $(9,16,17)$.

\section{Statistics analysis}

EXCEL 2013 software and SPSS version 24 were used for data and statistical analysis, respectively. P-value $<0.05$ was significant.

\section{RESULTS}

The results obtained show that there is a significant relationship between $\mathrm{mAs}$ and $\mathrm{kVp}$ changes with ED and ESD values. The p-value for Chest and Skull examinations is 0.011 and 0.0001 , respectively. Table 1 shows demographic information and technical parameters related to the Chest and Skull examinations at three hospitals in Khorramabad. In this study, $61.81 \%$ of patients were male, and the rest were female. In this table, the range of $\mathrm{kVp}$, mAs, and FFD parameters for both Chest and Skull examinations were reported.

ESD range in Chest PA, Chest LAT, Skull PA, and Skull LAT examinations were $0.1075-0.8844,0.2059-2.2997,0.0729-1.44$ and 0.03478-1.15 mGy respectively.

Figure 1 shows the mean ESD in three hospitals in comparison with those published by reference organizations. In this study, it has resulted that the average ESD for all examinations in hospital $A$ is lower than in hospital B, and in hospital C, it is less than other hospitals as well as related organizations.

Figure 2 shows the mean dose received by the vital organs for each of the four procedures at three hospitals. In these examinations, reproductive organs such as ovaries and testes did not receive a significant dose, so they were omitted from the figure. The most value of absorption dose in Chest PA (0.712 mGy), Chest LAT (0.2 mGy), Skull PA (0.27 mGy)and Skull LAT (0.48 mGy) examination is for the thymus, breast and lung, thyroid and Upper spine respectively.

In figure 3, the mean effective dose for the 
examinations performed in this study was compared with the ED in some other studies. In this study, ED for all examinations in three hospitals is higher than related organizations.

Table 2 shows the effective dose, the cumulative effective dose, the number of radiographs per year, and additional cancer caused by the types of radiographs. The most effective dose related to Skull PA in Hospital C $(0.14 \mathrm{mGy})$. The total annual radiation dose in the three hospitals in Khorramabad, which had a population, was 2.74 person-Sv.

Table 1. demographic and technical parameters for radiographic examinations.

\begin{tabular}{|c|c|c|c|c|}
\hline $\begin{array}{c}\text { Demographic \& } \\
\text { Exposure parameters }\end{array}$ & Examinations & Gender & Number & Mean士SD \\
\hline \multirow[t]{4}{*}{ 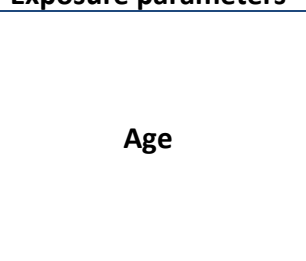 } & Chest/PA & $\begin{array}{c}\text { Male } \\
\text { Female }\end{array}$ & $\begin{array}{l}14 \\
11\end{array}$ & $\begin{array}{c}46 \pm 17.47 \\
55.33 \pm 14.60\end{array}$ \\
\hline & Chest/LAT & $\begin{array}{c}\text { Male } \\
\text { Female }\end{array}$ & $\begin{array}{l}14 \\
11\end{array}$ & $\begin{array}{c}46 \pm 16.84 \\
57.09 \pm 13.98\end{array}$ \\
\hline & Skull/PA & $\begin{array}{c}\text { Male } \\
\text { Female }\end{array}$ & $\begin{array}{c}17 \\
9\end{array}$ & $\begin{array}{c}7.66 \pm 4.64 \\
39.88 \pm 24.30\end{array}$ \\
\hline & Skull/LAT & $\begin{array}{c}\text { Male } \\
\text { Female }\end{array}$ & $\begin{array}{c}17 \\
9\end{array}$ & $\begin{array}{c}7.66 \pm 4.64 \\
39.88 \pm 24.30\end{array}$ \\
\hline \multirow{4}{*}{ Height } & Chest/PA & $\begin{array}{c}\text { Male } \\
\text { Female }\end{array}$ & $\begin{array}{l}14 \\
12\end{array}$ & $\begin{array}{c}161 \pm 41.54 \\
148.07 \pm 39.33\end{array}$ \\
\hline & Chest/LAT & $\begin{array}{l}\text { Male } \\
\text { Female }\end{array}$ & $\begin{array}{l}14 \\
12\end{array}$ & $\begin{array}{l}172.92 \pm 8.58 \\
157.08 \pm 7.67\end{array}$ \\
\hline & Skull/PA & $\begin{array}{l}\text { Male } \\
\text { Female }\end{array}$ & $\begin{array}{l}19 \\
7\end{array}$ & $\begin{array}{l}128.86 \pm 32.06 \\
144.83 \pm 38.43\end{array}$ \\
\hline & Skull/LAT & $\begin{array}{c}\text { Male } \\
\text { Female }\end{array}$ & $\begin{array}{c}19 \\
7\end{array}$ & $\begin{array}{l}128.86 \pm 32.06 \\
144.83 \pm 38.43\end{array}$ \\
\hline \multirow{4}{*}{ Weight } & Chest/PA & $\begin{array}{c}\text { Male } \\
\text { Female }\end{array}$ & $\begin{array}{l}14 \\
12\end{array}$ & $\begin{array}{l}78.53 \pm 15.93 \\
71.30 \pm 15.74\end{array}$ \\
\hline & Chest/LAT & $\begin{array}{c}\text { Male } \\
\text { Female }\end{array}$ & $\begin{array}{l}14 \\
12\end{array}$ & $\begin{array}{l}82.21 \pm 13.88 \\
71.83 \pm 16.27\end{array}$ \\
\hline & Skull/PA & $\begin{array}{l}\text { Male } \\
\text { Female }\end{array}$ & 20 & $\begin{array}{l}42.45 \pm 67.49 \\
54.66 \pm 18.34\end{array}$ \\
\hline & Skull/LAT & $\begin{array}{c}\text { Male } \\
\text { Female }\end{array}$ & $\begin{array}{c}20 \\
7\end{array}$ & $\begin{array}{l}42.45 \pm 67.49 \\
54.66 \pm 18.34\end{array}$ \\
\hline \multirow{4}{*}{ KV } & Chest/PA & $\begin{array}{c}\text { Male } \\
\text { Female }\end{array}$ & $\begin{array}{l}14 \\
12\end{array}$ & $\begin{array}{l}60.92 \pm 5.12 \\
60.41 \pm 5.21\end{array}$ \\
\hline & Chest/LAT & $\begin{array}{c}\text { Male } \\
\text { Female }\end{array}$ & $\begin{array}{l}14 \\
12\end{array}$ & $\begin{array}{l}68.35 \pm 5.85 \\
68.08 \pm 5.23\end{array}$ \\
\hline & Skull/PA & $\begin{array}{c}\text { Male } \\
\text { Female }\end{array}$ & $\begin{array}{c}20 \\
9\end{array}$ & $\begin{array}{c}65.65 \pm 9.5 \\
63.11 \pm 5.42\end{array}$ \\
\hline & Skull/LAT & $\begin{array}{c}\text { Male } \\
\text { Female }\end{array}$ & $\begin{array}{c}20 \\
9\end{array}$ & $\begin{array}{c}63.75 \pm 10.66 \\
62.66 \pm 6.21\end{array}$ \\
\hline \multirow{4}{*}{ mAs } & Chest/PA & $\begin{array}{l}\text { Male } \\
\text { Female }\end{array}$ & $\begin{array}{l}14 \\
12\end{array}$ & $\begin{array}{c}7.6 \pm 2.27 \\
7.29 \pm 3.14\end{array}$ \\
\hline & Chest/LAT & $\begin{array}{l}\text { Male } \\
\text { Female }\end{array}$ & $\begin{array}{l}14 \\
12\end{array}$ & $\begin{array}{c}10.63 \pm 4.68 \\
11.1 \pm 4.56\end{array}$ \\
\hline & Skull/PA & $\begin{array}{c}\text { Male } \\
\text { Female }\end{array}$ & $\begin{array}{c}20 \\
9\end{array}$ & $\begin{array}{l}8.54 \pm 4.89 \\
9.58 \pm 3.68\end{array}$ \\
\hline & Skull/LAT & $\begin{array}{c}\text { Male } \\
\text { Female }\end{array}$ & $\begin{array}{c}20 \\
9\end{array}$ & $\begin{array}{l}7.81 \pm 4.67 \\
9.86 \pm 3.80\end{array}$ \\
\hline \multirow{4}{*}{ Calculated Dose (mGy) } & Chest/PA & $\begin{array}{c}\text { Male } \\
\text { Female }\end{array}$ & $\begin{array}{l}14 \\
12\end{array}$ & $\begin{array}{l}0.29 \pm 0.16 \\
0.34 \pm 0.26\end{array}$ \\
\hline & Chest/LAT & $\begin{array}{l}\text { Male } \\
\text { Female }\end{array}$ & $\begin{array}{l}14 \\
12\end{array}$ & $\begin{array}{l}0.64 \pm 0.55 \\
0.58 \pm 0.41\end{array}$ \\
\hline & Skull/PA & $\begin{array}{c}\text { Male } \\
\text { Female }\end{array}$ & $\begin{array}{c}20 \\
9\end{array}$ & $\begin{array}{l}0.53 \pm 0.37 \\
0.60 \pm 0.24\end{array}$ \\
\hline & Skull/LAT & $\begin{array}{l}\text { Male } \\
\text { Female }\end{array}$ & $\begin{array}{c}20 \\
9\end{array}$ & $\begin{array}{l}0.60 \pm 0.22 \\
0.49 \pm 0.29\end{array}$ \\
\hline \multirow{4}{*}{ FFD $(\mathrm{cm})$} & Chest/PA & $\begin{array}{l}\text { Male } \\
\text { Female }\end{array}$ & $\begin{array}{l}14 \\
12\end{array}$ & $\begin{array}{c}171 \pm 12.26 \\
171.53 \pm 12.91\end{array}$ \\
\hline & Chest/LAT & $\begin{array}{c}\text { Male } \\
\text { Female }\end{array}$ & $\begin{array}{l}14 \\
12\end{array}$ & $\begin{array}{l}162.85 \pm 14.84 \\
156.83 \pm 12.55\end{array}$ \\
\hline & Skull/PA & $\begin{array}{c}\text { Male } \\
\text { Female }\end{array}$ & $\begin{array}{c}20 \\
9\end{array}$ & $\begin{array}{c}89.5 \pm 12.13 \\
89.44 \pm 11.88\end{array}$ \\
\hline & Skull/LAT & $\begin{array}{c}\text { Male } \\
\text { Female }\end{array}$ & $\begin{array}{c}20 \\
9\end{array}$ & $\begin{array}{l}87.25 \pm 11.88 \\
89.44 \pm 14.22\end{array}$ \\
\hline
\end{tabular}




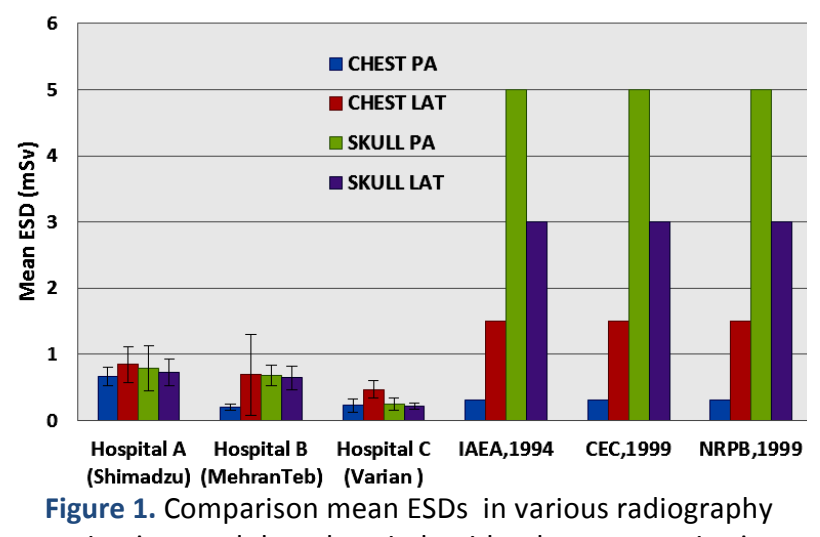

examinations and three hospitals with relevant organizations.

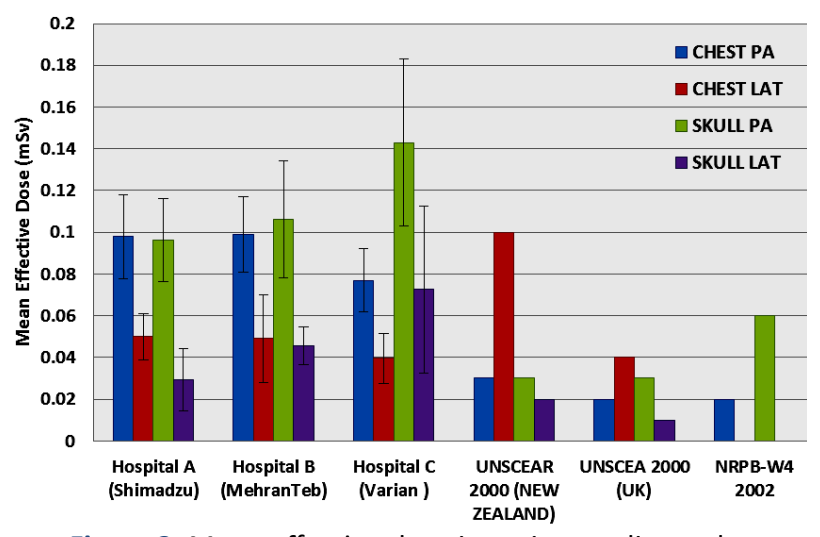

Figure 3. Mean effective dose in various radiography examinations and three hospitalscomparedwith references values.

\section{DISCUSSION}

In this study, we investigated radiation dose in common Chest and Skull radiographic examinations in 3 general hospitals in Khorramabad. The results showed that the ESD values were It is comparable to the study of Bouzarjomehri, Iran (18) and Ackom et al., Ghana (19).

Moreover, As shown in Figure 1, all mean values of ESD in this study were lower than the diagnostic reference dose for radiographic examinations (proportional to DRLs recommended by the NRPB, IAEA, and CEC) (9-11, 20). On the other hand, according to table 3 , we observed that the mean values of ESD in the Chest examination are close to those of other studies in Iran; however, they are higher than the mean of other studies in other countries. One of the possible reasons for the higher mean ESD in the Chest examination is that most radiology technicians uses FFDs $<180 \mathrm{~cm}$ Int. J. Radiat. Res., Vol. 19 No. 4, October 2021

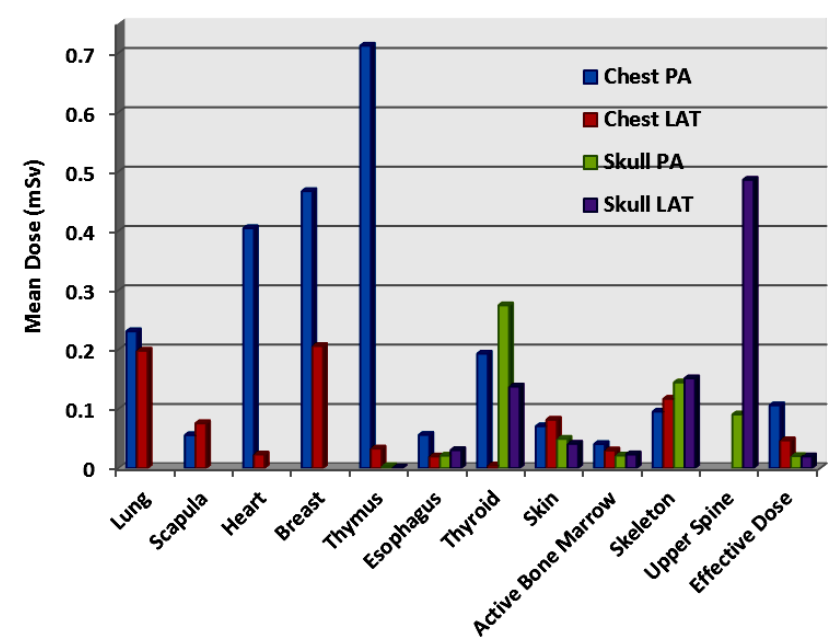

Figure 2. Mean ESD in various radiography examinations.

Table 2. Statistical and dosimetric data in various examinations and cancer risk assessment.

\begin{tabular}{|c|c|c|c|c|}
\hline $\begin{array}{c}\text { Examination } \\
\text { type }\end{array}$ & $\begin{array}{c}\text { Mean effective } \\
\text { dose foe each } \\
\text { examination/ } \\
\text { mSv }\end{array}$ & $\begin{array}{c}\text { Number of } \\
\text { examination } \\
\text { I year }\end{array}$ & $\begin{array}{c}\text { Collective } \\
\text { effective } \\
\text { dose/ } \\
\text { person-Sv }\end{array}$ & $\begin{array}{c}\text { Cancer risk } \\
\text { assessment } \\
\text { I year }\end{array}$ \\
\hline Chest PA & 0.10 & 19945 & 2.11 & 0.1057 \\
\hline Chest LAT & 0.04 & 12652 & 0.59 & 0.0297 \\
\hline Skull PA & 0.02 & 1020 & 0.02 & 0.001 \\
\hline Skull LAT & 0.01 & 1150 & 0.02 & 0.0011 \\
\hline Total & 0.17 & 34767 & 2.74 & 0.1375 \\
\hline
\end{tabular}

(without reducing exposure conditions). The inaccurate design of the imaging room usually limits the application of FFD $=180 \mathrm{~cm}$. The mean values of ESD in the Skull examination in this study were significantly lower than those of other studies in Iranand other countries. Since the rate of overexposed films on Skull radiography was relatively considerable, and they were excluded from sampling, this may also be the reason for the decrease in ESD.

Furthermore, The difference in ESD may be attributed to several factors, such as differences in patient weight and exposure parameters. In the present study, ESDs increased in hospitals using older devices, which is consistent with the findings of Gholami et al. (21). Equipment performance (especially film speed) and filtration can also be the most important factors affecting ESD. These findings are consistent with the IAEA recommendation and also the results of studies by Alghahtani et al. (22), as well as Hart et al. (20) and Saeed et al. (23), who all reported an 
increase in film speed from 200 to 400 by decreasing patient dose almost by half. Similar to Osman et al.'s study, according to table 1 and ESD measurements under identical irradiation conditions, a direct and linear relationship was also found between ESD and factors such as height and weight (24).

In this study, ESD measurements were performed experimentally using TLD, while some studies have calculated the ESD value using simulation software due to restricted access to dosimeters $(25,26)$. Some studies have also calculated ESD with specicformulas from other radiation parameters such as X-ray Output Device (27-30). Therefore, one of the possible reasons for the difference in measured dose values can be the difference in the method of ESD determination.

Table 3. ESD in chest and skull examinationscompared to those values in Iran and other countries.

\begin{tabular}{|c|c|c|}
\hline & \multicolumn{2}{|c|}{ Examination Type } \\
\hline & Chest & Skull \\
\hline Mean ESD (This Study) (mGy) & 0.51 & 0.54 \\
\hline \multicolumn{3}{|c|}{ Mean ESD (different cities of Iran) (mGy) } \\
\hline Mashhad $^{(36)}$ & 0.34 & 1.78 \\
\hline Kashan $^{(3 /)}$ & 0.37 & 1.39 \\
\hline ChaharmahalBakhtiari $^{(38)}$ & 0.7 & 6.92 \\
\hline $\operatorname{Iran}^{(39)}$ & 0.41 & 2.83 \\
\hline Esfahan $^{(40)}$ & 0.74 & 6.84 \\
\hline Hamedan $^{(34)}$ & 0.43 & 2.15 \\
\hline Mean ESD (in other studies in Iran) & 0.49 & 3.71 \\
\hline \multicolumn{3}{|c|}{ Mean ESD (other countries) (mGy) } \\
\hline Serbia[41] & 0.43 & - \\
\hline Serbia and Montenegro ${ }^{(42)}$ & 0.4 & 1.15 \\
\hline $\mathrm{UK}^{(43)}$ & 0.16 & 3 \\
\hline Portugal $^{(44)}$ & 0.31 & - \\
\hline Italy ${ }^{(45)}$ & 0.57 & 7.38 \\
\hline Slovenia ${ }^{(44)}$ & 0.23 & - \\
\hline Romania $^{(44)}$ & 1.7 & 11 \\
\hline Greece $^{(44)}$ & 0.69 & 3.5 \\
\hline Canada $^{(35)}$ & 0.14 & 1.67 \\
\hline Serbia and Montenegro ${ }^{(46)}$ & 0.33 & 1.15 \\
\hline $\mathrm{HPA}^{(4 /)}$ & 0.2 & 3 \\
\hline Canada $^{(27)}$ & 0.17 & 1.57 \\
\hline Canada ${ }^{(48)}$ & 0.11 & 1.64 \\
\hline$U^{(49)}$ & 0.15 & 1.18 \\
\hline Mean ESD (other countries) (mGy) & 0.37 & 3.29 \\
\hline
\end{tabular}

According to figure 3and table 4, can be seen that in almost all hospitals, the effective dose is higher than other studies, which may be due to the lack of efficient health physicists to train choosing optimal $\mathrm{kVp}, \mathrm{mAs}$, and FFD, and also their calibration system, which is consistent with the findings of Vassileva et al. and Gholami et al. (31,32).

Table 4. Effectivedosein chest and skull examinations compared to those values in Iran and other countries.

\begin{tabular}{|c|c|c|}
\hline & \multicolumn{2}{|c|}{ Examination Type } \\
\hline & Chest & Skull \\
\hline Mean ED (This Study) (mSv) & 0.07 & 0.02 \\
\hline \multicolumn{3}{|c|}{ Mean ED (other studies) (mSv) } \\
\hline Serbia $^{(47)}$ & 0.03 & - \\
\hline Kashan $^{(37)}$ & 0.04 & 0.01 \\
\hline UK E-103 ${ }^{(50)}$ & 0.01 & 0.02 \\
\hline Esfahan $^{(40)}$ & 0.11 & 0.07 \\
\hline Canada ${ }^{(35)}$ & 0.02 & 0.02 \\
\hline Canada ${ }^{(27)}$ & 0.04 & 0.01 \\
\hline Serbia and Montenegro ${ }^{(46)}$ & 0.02 & - \\
\hline UK E-60 ${ }^{(49)}$ & 0.01 & 0.02 \\
\hline Hamedan $^{(34)}$ & 0.03 & 0.02 \\
\hline $\begin{array}{l}\text { Mean ED (other studies) } \\
\text { (mSv) }\end{array}$ & 0.03 & 0.02 \\
\hline
\end{tabular}

Further, according to the results obtained by De Oliviera et al., PCXMC software usually overestimates the effective dose. In contrast, CALDose- $X$ software estimates the effective dose closer to the actual values (33). It seems that one of the reasons for the high effective dose in this study compared to other ones was the difference between the dose calculation software and how to calculate the method with other studies $(27,30$, $34,35)$.

The cumulative effective dose calculations (for the Khorramabad population), the number of radiographs per year, and additional cancer caused by the Chest and Skull radiographic examinations are shown in table 2. Therefore, since only the dose of these examinations is considered, the cumulative effective dose is not significant; if the dose of higher absorbed dose examinations such as CT scans, fluoroscopy, angiography, etc. is added to them, this value will increase significantly. This confirms the need to continue such studies and to extend them to other X-ray diagnostic methods.

Int. J. Radiat. Res., Vol. 19 No. 4, October 2021 


\section{CONCLUSION}

In this study, the mean ESD estimated was lower than the DRL recommended by NRPB, CEC, and IAEA, but the calculated ED was almost higher than other studies. Factors such as the performance and up-to-date equipment used, and the use of high-speed films are effective in reducing ESD/ED. In addition, conducting retraining courses for radiology staff is critical for achieving the best ALARA with the highest-quality medical images.

\section{Conflicts of interest: Declared none.}

\section{REFERENCES}

1. Kim S and Cho K (2016) Analysis of university student awareness of radiation exposures from consumer products. J Radiat Prot Res, 41(1): 57-70.

2. van der Meij EH, Karagozoglu KH, de Visscher J (2018) The value of cone beam computed tomography in the detection of salivary stones prior to sialendoscopy. Int J Oral Maxillofac Surg, 47(2): 223-7.

3. Chang K-P, Hsu T-K, Lin W-T, Hsu W-L (2017) Optimization of dose and image quality in adult and pediatric computed tomography scans. Radiat Phys Chem, 140: 260-5.

4. Hendee WR and O'Connor MK (2012) Radiation risks of medical imaging: separating fact from fantasy. Radiology, 264(2): 312-21.

5. Groenewald A and Groenewald W (2014) Reduction of radiation dose and relative risk of cancer induction to neonates receiving anteriorposterior chest X-ray. GJSFR, 14(3): 32-9.

6. Karami V, Zabihzadeh M, Keshtkar M (2017) Evaluation of the Entrance Surface Dose (ESD) and Radiation Dose to the Radiosensitive Organs in Pediatric Pelvic Radiography. Int J Pediatr, 5(6): 5013-22.

7. Boice JD Jr. (2018) NCRP vision for the future and program area committee activities in 2017. Health Phys, 114(2): 232-42.

8. Kamei O, Ojima M, Yoshitake T, Ono K, Nishijima K, Kai M (2015) Calculating patient-specific organ doses from adult body CT scans by Monte Carlo analysis using maleindividual voxel phantoms. Health Phys, 108(1): 44-52.

9. Valentin J (2007) The 2007 recommendations of the international commission on radiological protection. ICRP publication 103. Ann iCRP, 37(2): 1-332.

10. Food, Agriculture Organization of the United Nations (1994) International basic safety standards for protection against ionizing radiation and for the safety of radiation sources Interim ed. IAEA.

11. Directive C (1997) 97/43/Euratom of 30 June 1997 on health protection of individuals against the dangers of ionizing radiation in relation to medical exposure, and repealing Directive 84/466/Euratom. OJ, 180(09): 07.

12. Samba ON, Yomi J, Juimo AG, Lukong FC (2015) Local reference dose level evaluation in chest radiography in $\mathrm{Ya}$ ounde. JAIM, 7(3): 152-62.

13. Gholami M, Zare S, Saki A, Piri Z, Mousavi M (2017) Assessment of patient radiation dose in interventional procedures at Shahid Madani heart center in Khorramabad, Iran. IJMP, 14(3): 128-34.

14. Herath $L$ and Rosairo S (2016) Effective dose and dose area product assessment for postero-anterior erect chest X-ray examinations of adult patients in a selected teaching hospital in Srilanka. Proceedings in Medical, Allied Health, Basic and Applied Sciences, 9th International Research Conference, KDU, Sri Lanka: 6-11.

15. apiovaara M, Siiskonen T (2008) PCXMC, a Monte Carlo program for calculating patient doses in medical x-ray examinations. Radiation and Nuclear Safety Authority STUK.

16. Tapiovaara M, Siiskonen T (2008) PCXMC 2.0: User's Guide.

17. Thorne M (1992) ICRP publication 60: 1990 recommendations of the international commission on radiological protection: Annals of the ICRP, 21(1-3): 1991.

18. Bouzarjomehri $F(2004)$ Patient dose in routine X-ray examinations in Yazd state. Int J Radiat Res, 1(4): 199-204.

19. Ackom D, Sosu E, Inkoom S, Schandorf C (2017) Estimation of Entrance Surface Dose of Adult Patients undergoing Computed Radiography Examinations in Two Hospitals. Int J Adv Res Sci Eng Technol, 3: 746-52.

20. Hart D andWall B (2002) Radiation exposure of the UK population from medical and dental X-ray examinations. NRPB Chilton, UK.

21. Gholami M, Nemati F, Karami V (2015) The evaluation of conventional X-ray exposure parameters including tube voltage and exposure time in private and governmental hospitals of Lorestan Province, Iran. IJMP, 12(2): 85-92.

22. Alqahtani JM (2017) The abdominal radiation doses for paediatric patients undergoing $\mathrm{X}$-ray examinations at southern Saudi Arabia. Australas Phys Eng Sci Med, 40(2): 427-32.

23. Saeed MK (2015) Regional survey of entrance surface dose to patients from X-ray examinations in Saudi Arabia. Australas Phys Eng Sci Med, 38(2): 299-303.

24. Osman H, Sulieman A, Suliman II, Sam AK (2010) Radiation dose measurements in routine $\mathrm{X}$-ray examinations. Tenth Radiation Physics \& Protection Conference, Nasr City Cairo, Egypt, 287-294.

25. Esen Nsikan U and Obed RI (2015) Assessment of patientsâ entrance skin dose from diagnostic $X$-ray examinations at public hospitals of Akwa Ibom State, Nigeria. IJMP, 12(2): 93-100. 
26. Yacoob HY and Mohammed HA (2017) Assessment of patients X-ray doses at three government hospitals in Duhok city lacking requirements of effective quality control. J Radiat Res Appl Sci, 10(3): 183-7.

27. Compagnone G, Pagan L, Bergamini C (2005) Local diagnostic reference levels in standard $\mathrm{X}$-ray examinations. Radiat Prot Dosimetry, 113(1): 54-63.

28. Imeh EE, Imaobong E, Samuel IO, Ukeme U (2018) Estimation of entrance surface dose and sex specific effective doses during chest $\mathrm{X}$-ray examinations in diagnostic radiology facilities. AJMP, 1(1): 52.

29. Mirdoraghi M, Banaei A, Fatahi Asl J (2018) Data on the estimating the risk of cancer due to some common radiographs in Tehran city. Data Brief, 20: 1269-73.

30. Vodovatov AV, Balonov MI, Golikov VY, Shatsky IG, Chipiga LA, Bernhardsson C (2017) Proposals for the establishment of national diagnostic reference levels for radiography for adult patients based on regional dose surveys in Russian Federation. Radiat Prot Dosimetry, 173(1-3): 223-32.

31. Vassileva J, Dimov A, Slavchev A, Karadjov A (2005) Bulgarian experience in the establishment of reference dose levels and implementation of a quality control system in diagnostic radiology. Radiat Prot Dosimetry, 117(1-3): 1314.

32. Gholami M, Maziar A, Khosravi H, Ebrahimzadeh F, Mayahi S (2015) Diagnostic reference levels (DRLs) for routine Xray examinations in Lorestan province, Iran. Int J Radiat Res, 13(1): 85-90.

33. De Oliveira PMC, Squair PL, Lacerda MA, Da Silva TA (2011) Assessment of organ absorbed doses in patients undergoing chest X-ray examinations by Monte Carlo based softwares and phantom dosimetry. Radiat Meas, 46 (12): 2073-6.

34. Nikzad S, Pourkaveh M, Vesal NJ, Gharekhanloo F (2018) Cumulative radiation dose and cancer risk estimation in common diagnostic radiology procedures. Iran J Radiol, 15 (3): $e 60955$

35. Osei EK and Darko J (2013) A survey of organ equivalent and effective doses from diagnostic radiology procedures. ISRN Radiol, 2013: 204346.

36. Bahreyni Toossi MT and Malekzadeh M (2012) Radiation dose to newborns in neonatal intensive care units. Iran J Radiol, 9(3): 145-9.

37. Aliasgharzadeh A, Mihandoost E, Masoumbeigi M, Salimian $M$, Mohseni $M$ (2015) Measurement of entrance skin dose and calculation of effective dose for common diagnostic X-ray examinations in Kashan, Iran. Glob J Health Sci, 7(5): 202-7.
38. Shahbazi-Gahrouei D (2006) Entrance surface dose measurements for routine $\mathrm{X}$-ray examinations in Chaharmahal and Bakhtiari hospitals. IJMP, 4(1): 29-34.

39. Asadinezhad M, Bahreyni Toossi MT (2008) Doses to patients in some routine diagnostic $\mathrm{X}$-ray examinations in Iran: proposed the first Iranian diagnostic reference levels. Radiat Prot Dosimetry, 132(4): 409-14.

40. Shahbazi-Gahrouei D, Baradaran-Ghahfarokhi M (2013) Assessment of entrance surface dose and health risk from common radiology examinations in Iran. Radiat Prot Dosimetry, 154(3): 308-13.

41. Ciraj O, Markovic S, Kosutic D (2003) Patient dosimetry in diagnostic radiology. Nucl Technol Radiat Prot, 18(1):3641.

42. Ciraj O, Markovic S, Kosutic D (2005) Patient doses from conventional diagnostic radiology procedures in Serbia and Montenegro. Recent Advances in Multidisciplinary Applied Physics: Elsevier, 77-84.

43. Shrimpton PC, Wall BF, Jones DG, Fisher ES, Hillier MC, Kendall GM, et al. (1986) Doses to patients from routine diagnostic X-ray examinations in England. Br J Radiol, 59 (704): 749-58.

44. Radiation UNSCotEoA (2000) Sources and effects of ionizing radiation: sources. United Nations Publications.

45. Padovani R, Contento G, Fabretto M, Malisan MR, Barbina V, Gozzi G (1987) Patient doses and risks from diagnostic radiology in North-east Italy. BrJ Radiol, 60(710): 155-65.

46. Ciraj O, Markovic S, Kosutic D (2005) First results on patient dose measurements from conventional diagnostic radiology procedures in Serbia and Montenegro. Radiat Prot Dosimetry, 113(3): 330-5.

47. HPA Recommended national reference doses for individual radiographs on adult patients. Health Protection Agency. Centre for Radiation, Chemical and Environmental Hazards; 2000.

48. Compagnone G, Pagan L, Baleni MC, Calzolaio FL, Barozzi L, Bergamini C (2008) Patient dose in digital projection radiography. Radiat Prot Dosimetry, 129(1-3): 135-7.

49. Hart D, Hillier M, Shrimpton P (2012) Doses to Patients from Radiographic and Fluoroscopic X-ray Imaging Procedures in the UK -2010 review. Chilton: HPA.

50. Wall B, Haylock R, Jansen J, Hillier M, Hart D, Shrimpton $P$ (2011) Radiation risks from medical X-ray examinations as a function of the age and sex of the patient. Chilton, Didcot Oxfordshire OX11 ORQ ISBN. Health Protection Agency, Centre for Radiation. Chemical and Environmental Hazards 978-0 $p$. 